\title{
The Long-Run and Short-Run Endogeneity of Money Supply in the Republic of Macedonia: An Empirical Analysis
}

\author{
Ph.D. Candidate Milica Milosheska Gavrovska (Komercijalna Banka AD Skopje, Macedonia) \\ Prof. Dr. Trajko Slaveski (Ss. Cyril and Methodius University, Macedonia)
}

\begin{abstract}
The aim of this paper is to assess the endogenous and exogenous approaches on the money creation process on empirical grounds, through analysis in the case of the Republic of Macedonia.

Using the ARDL econometric model, it has been determined that the money supply in the Republic of Macedonia in the period January 2003 - August 2018 is endogenously determined in the long run. The empirical results in the short term show bidirectional causality between deposits and monetary base, as well as between deposits and loans.

However, in the end, the central bank in the Republic of Macedonia has an influence on the money supply. The exogenous monetary policies based on money supply control, can positively influence the amount of liquidity held by commercial banks and, hence, increase the supply of loans, but the demand for loans is still important when stimulating the entry of liquidity in the real economy.
\end{abstract}

\section{Introduction}

After the financial crisis and the great recession (2007-2009) that has recently upset the world economy, the public is preoccupied with how the banks came to so much money. Until this period, in the economics textbooks, the traditional theory of the money creation process was mainly represented as a product of the monetary base and the money multiplier, i.e. the money supply was considered exogenous. Experts in economic and professional circles believe that they know how the money is created.

But the Great Recession opened a debate about "who creates money," through a bond of money in circulation offered by the central bank, and inside money, created by commercial banks. The essence of money is closely related to the process of their creation. It does not matter what the money is, but the effect it has. The fact that the deep recession hit the advanced economies that had solid institutions and well-informed regulatory authorities was surprising.

The Post-Keynesian economists seriously questioned the validity of the traditional theory of the money creation process. Based on historical events and empirical evidence, the researchers strongly suggested that the money supply was endogenous and determined by the demand for credit money. This is considered a post-Keynesian invention.

In the modern economy, most money is in the form of bank deposits. The main way in which bank deposits are created is via commercial banks that approve loans. Namely, in the modern banking system, banks create money using the lending mechanism, but only generate money in the form of bank deposits. Banks create deposits as a by-product of their lending. Whenever the bank approves a loan, it creates an appropriate deposit in the bank account of the borrower, creating new money. Only central banks create cash. The amount of money created in the economy in the end, depends on the monetary policy of the Central Bank.

After the Great Recession, banks are increasingly incorporated into macroeconomic models. Until then, banks were not part of the macroeconomic models. The reason for this is that in the past decades, and as a result of careful banking regulation, the private banking system was not an important source of instability. But the great recession has caused a dramatic change. The role of the banks in the economy attracted attention more than ever, whereupon the creators of the monetary policy clearly recognizing the importance of a sound banking system for the real economy.

This paper will consider the current issue of creating money in the case of the Republic of Macedonia, by analyzing the connection between the variables determining the money supply, and taking into account the characteristics of the Macedonian banking system. The paper is organized as follows: the second part gives an overview of theoretical and empirical literature, the third part explains the endogenous and exogenous process of money creation, in the fourth part the role of the banks in the money creation process is reviewed, the fifth part describes the data and methodology and presents the empirical results. The conclusions and political implications follow in the last section.

\section{Literature Review}

A considerable body of literature is devoted to the money creation. To the best of our knowledge, no one attempted to test the endogenous hypothesis for the less developed countries, except Ahmad, N. \& Ahmet, F. (2006) for Pakistan. Ironically, low-income countries are blessed with high unemployment and corruption. A 
recommendation that is often suggested by the Keynesians is to follow active monetary and fiscal policies to avoid the problem of high unemployment. Researches in this area have not been found in Macedonian literature.

The fact that banks create their own funds through lending is also emphasized in the older economic literature. One of the earliest statements is according to Wicksell (1906): "The lending operations of the bank will consist rather in its entering in its books a fictitious deposit equal to the amount of the loan...”. Rogers (1929): “... a large proportion of ... [deposits] under certain circumstances may be manufactured out of whole cloth by the banking institutions themselves."

The theoretical literature proposed arguments to support the endogeneity of money. To test this theoretical argument, the empirical literature on money endogeneity for different economies has shown that the money supply is endogenously determined. For example, Enrico, S., L. and Matteo, D. (October, 2017), Paul, M. and Joshua, W. (2013), Milena, L. (August 2014), Haghighat, J. (2012), Alexey, P. (2016), Vera, AP (2001), Shanmugam, B., Nair, M. and Li, O.W. (2003) presented a time analysis to test the money-endogeneity hypothesis in the case of the United States, the Eurozone countries, Iran, the emerging economies, Spain, and Malaysia, respectively.

The empirical results show that there is a causal link between loans to bank deposits, monetary base, and monetary aggregates. But in addition to these studies that prove the endogenous process of money creation, there are also studies where the obtained results prove that in some periods the money supply is exogenously determined. For example, according to Ahmad's empirical findings, N. \& Ahmet, F. (2006), in their research on the short-term and long-term endogeneity of the money supply in Pakistan, the money supply is endogenously determined only in the short term, the time period is not longer than 18 months, but in the long run the money supply is exogenous, that is, the central bank has a significant influence on the money supply in the long run. The result of their analysis is that monetary policy can really affect the financial environment in the long run.

\section{Exogenous versus Endogenous Money Creation Process}

The ideological division between proponents of the theory of endogenous (horizontal) and exogenous (verticalist) money supply was fiercely expressed in the debates between the Post-Keynesians and the Monetarists from the late 1950 s to the early 1990s.

Economists have long talked about whether the money supply curve is vertical or horizontal. Verticalists claim that the money supply depends on the total reserves, while the reserves are the central bank's liabilities and are exogenously determined by the central bank, so the money supply should be displayed as a vertical line. While the Horizontalists argue that during the "market period", the central bank sets the interest rate and adjusts it to determine the liquidity of bank deposits, regardless of what reserves are required. Hence, the Horizontalists consider that the interest rate is exogenously determined, and the money supply is endogenously determined.

Modern undergraduate texts express the exogenous money creation (Blanchard, 2011; Mankiw, 2012; Frank \& Bernanke, 2013), that is a call to witness to the widespread acceptance of the Monotheistic view that is dominant. Given the importance of this issue, the endogenous view of bank money creation has relatively discreetly emerged as a view expressed by modern monetarists (McLeay, Radia, \& Thomas, 2014a \& 2014b), which probably provoked excessive controversy. With the exogenous view as a precedent in the past half-century, the unfortunate by-product was focused on money creation, which focused on money supply, treating the given demand for money as a past. Despite the change in the endogenous explanation of the money supply, the focus of monetary policy remained on the offer side, with a relatively small focus on the basic demand for money, despite its recognized importance in the theory of endogenous money.

According to the horizontal description of bank money creation, the bank approves a loan to a client, whereby it lends its bank account with the amount of deposit equal to the size of the loan. This is bank money creation. No physical cash is required for these accounting records. This description represents an endogenous approach to the money creation process, and this process is specified as "loans create deposits" (McLeay, Radia, \& Thomas, 2014b). Hence, the money supply is determined by the demand for credit money. Debtors base the demand for credits considering their expectations for future income. The endogeneity of money causes a causative direction from loans to bank deposits. At the same time, deposits created with new loans are used to finance the rise in aggregate demand. And monetary policy has an impact both on the monetary base and on the money supply. The change in money supply causes interest rate fluctuations, which further affects investment and income.

According to the Verticalists' view, the bank borrows cash that the clients previously physically deposited in the bank. Loan approval once again, creates an entry on the deposit obligation; however, bank money was created in this process after the bank will transfer the existing physical cash deposits to customers. This process is specified as "deposits creating loans" and is an exogenous view of the money supply.

With the acknowledged inability of central banks to directly control the supply of money, the discussion on monetary policy focused on banks as money generators. However, a superficial treatment of the money demand and the focus of the banks as money generators, it explains fundamentally the role of banks in the money creation process. 


\section{The Role of Banks in the Money Creation Process}

The role of the banks in the economy attracted attention more than ever, whereupon the monetary policy makers clearly recognize the importance of a sound banking system for the real economy.

According to Jan (2014), the main activity of banks is to facilitate the process of inter-time exchange of transactions between buyers and sellers through loan agreements. Banks are financial intermediaries which accept deposits, give loans and provide accounts for their clients.

One feature of the banks significantly differs them from other financial intermediaries. It is that their obligations, or at least their liabilities for sight deposits, serve as a generally accepted means of payment (James, 1963). In addition to banknotes and coins, deposit money is considered "money".

On the other hand, other financial institutions, unlike banks, do not generate money, and the amount of their assets is limited to the amount of their liabilities. They cannot count on receiving a "deposit" to coincide with any expansion of their lending. Only commercial banks have that freedom. And since they only have that key to unlimited expansion, the process of creating money is limited by regulatory factors - the central bank (reserve requirements). From the perspective of banks, the money creation is limited by the need for banks to lend profitably, and also from micro and macro prudential regulations. While the central bank affects the process of creating money by banks through its interest rate policy, which affects the financial and portfolio decisions of banks through different transmission channels.

\section{Analysis of the monetary base, bank deposits and bank credits in the case of the Republic of Macedonia}

\subsection{Data}

The analysis carried out in this paper is based on monthly data for the period January 2003 - August 2018, taken by the National Bank of the Republic of Macedonia for the following time series:

- total bank deposits,

- $\quad$ total bank credits and

- monetary base.

The time span allows us to use 188 observations in our time analysis. For all calculations the statistical software STATA is used. Before carrying out the analysis, a descriptive analysis of the time series was made.

\subsection{Methodology}

Since all variables assume positive value, the time series analysis will begin by transforming them into a logarithmic form and excluding the impact of seasonal variations with the MOVING AVERAGE technique.

We will apply times series models able to take into consideration and solve issues related to endogeneity. In order to arrange the data accurately, we implement the following steps.

Firstly, in order to understand the stationarity (or the order of integration) of considered variables, a standard unit root test is conducted on selected series. More specifically, two tests will be applied, including: Augmented Dickey-Fuller (ADF) and Phillips-Perron. Results concerning unit root, led us to use alternative econometric models in order to test short- and long-run causality between the variables.

Secondly, if the series are of the same order of integration, Johansen Cointegration Test will be applied to determine if there is cointegration among the variables. At the same time, VAR and VECM econometric models can be applied in order to determine the short- and long-run causality between the considered variables. The VAR model will estimate the short-run causality with the Granger non-Causality test, and VECM will estimate the shortrun causality with (Short-run Causality: Wald Test) and Long-Run Causality Test. However, if a unit root test shows that the variables are of different order of integration, i.e. I (0) and I (1), then the VECM model cannot be applied, but the alternative econometric model ARDL can also be applied because it estimates short- and long-run causality. ARDL model (Autoregressive Distributed Lag Modelling Approach) is developed by Pesaran(1997), Pesaran and Shin (1995, 1999),Pesaran and Smith, (1998), and Pesaran et al. (1996,2001).

\subsection{Empirical results and discussions}

For time series analysis, the data are taken in their logarithmic form, smoothing and seasonal adjustment is made with the MOVING AVERAGE technique. The smoothing is done with window (2 13 ):

$$
(1 / 6) *[\mathrm{x}(\mathrm{t}-2)+\mathrm{x}(\mathrm{t}-1)+1 * \mathrm{x}(\mathrm{t})+\mathrm{x}(\mathrm{t}+1)+\mathrm{x}(\mathrm{t}+2)+\mathrm{x}(\mathrm{t}+3)] ; \mathrm{x}(\mathrm{t})
$$




\begin{tabular}{|l|c|c|r|r|r|}
\hline Variables & Obs & Mean & Std. Dev. & Min & Max \\
\hline logmonetarybase ma & 188 & 3.848139 & .4700829 & 2.817185 & 4.538062 \\
\hline logtotalcredits ma & 188 & 5.032601 & .6248373 & 3.675591 & 5.726892 \\
\hline logtotaldeposits ma & 188 & 5.176848 & .5379969 & 3.98584 & 5.870641 \\
\hline
\end{tabular}

Table 1. Descriptive Statistics of the Considered Variables Source : Own Calculations

According to the obtained results with the Augmented Dickey-Fuller (ADF) and Phillips-Perron stationary tests, it has been established that the loans and deposits are stationary at level I (0), and the monetary base is stationary at first difference I (1), (Appendix2 ).

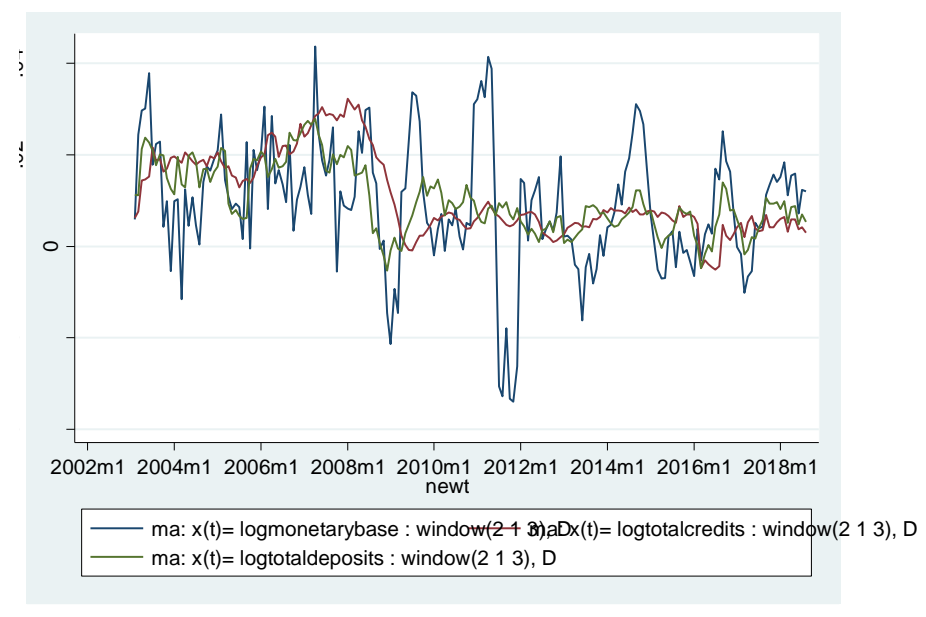

Graph 1. Graphical Representation of Stationary Time Series

Given that all three variables are at different order of integration, i.e. I (0), I (1) and I (1), it can be deduced that the ARDL econometric model can be implemented (Pesaran et al., 2001) that allows testing cointegration of the time series (the long-run equilibrium relationship between two or more variables). Additionally, the ARDL model provides an analysis of the causality even if the independent variables are endogenous, allowing the variables to have different optimal lag lengths and provides an opportunity to examine the short-run dynamics of the model versus the long-run relationship of the dependent and independent determinants. The theoretical ARDL is presented in the equation:

$$
\mathbf{y}_{t}=\beta_{0}+\beta_{1} \mathbf{y}_{t-1}+\ldots \ldots . .+\beta_{k} y_{t-p}+\alpha_{0} x_{t}+\alpha_{1} x_{t-1}+\alpha_{2} x_{t-2}+\ldots \ldots . . .+\alpha_{q} x_{t-q}+\varepsilon_{t}
$$

where, $y_{t}$ represents the dependent variable, $x_{t}$ represents the independent variable, $\varepsilon_{t}$ is standard long-term error, the symbols $\left(\beta_{1}-\beta_{\mathrm{k}}\right)$ in the first part of the equation denote the short-run coefficients, the symbols $\left(\alpha_{0}-\alpha_{\mathrm{q}}\right)$ denote the long-run coefficients, $p$ is the optimal time lag length.

To test whether there is a long-run relationship between the dependent variable and the independent variables in the model, i.e. whether there is a statistically significant cointegration between the time series we use the so-called "bound test", an approach developed by Pesaran and Pesaran (1997) and Pesaran et al. (2001). The zero hypothesis is that there is no statistically significant cointegration or long-run relationship between the dependent variable and the independent variables (Ho: $\beta 1=\beta 2=0$ ), contrary to the alternative hypothesis that at least one long-run coefficient is different from zero, which implies the existence of at least one long-run causality between a dependent and independent variable $(\mathrm{H} 1: \beta 1 \neq \beta 2 \neq 0)$.

The ARDL boundary test is based on the Wald test (F-statistics). The asymptotic distribution of the Wald test is non-standard in conditions of zero hypothesis when there is no cointegration between the determinants. Pesaran and Pesaran (1997) and Pesaran et al. (2001) set two critical values (lower and upper bounds) to test the cointegration. The lower critical bound value assumes that all variables are integrated at first difference $\mathrm{I}(1)$, while the upper bound critical value assumes that the determinants are integrated at zero difference $\mathrm{I}(0)$. Thus, if the obtained F-statistics exceeds the upper critical value, then the zero hypothesis is rejected, i.e. the alternative hypothesis that there is cointegration is accepted. On the other hand, if the obtained F-statistic does not exceed the lower critical value, then the zero hypothesis cannot be rejected, that indicates that there is no cointegration.

Given the assumption that all three variables in the paper are considered endogenous, three ARDL tests were made, each of the variables being dependent once. The results presented below, determine that there is a 1 (one) cointegration relationship in the long run, and therefore, loans and deposits have a significant impact on the monetary base in log-run.

The obtained test results presented in the table below indicate that the null hypothesis can be rejected, which means that there is a long-run relationship, i.e. cointegration between the determinants in the model (monetary 
base, total loans and total deposits). The obtained F-statistics is $\mathbf{6 . 3 4 5}$, that exceeds the upper critical value determined by Pesaran et al. (2001) with two regressors $(\mathrm{k}=2)$ at $1 \%$ level of significance.

\begin{tabular}{|c|c|c|c|c|c|c|c|}
\hline$[$ I_0] & {$\left[\mathrm{I} \_1\right]$} & {$\left[\mathrm{I} \_0\right]$} & {$\left[\mathrm{I} \_1\right]$} & {$\left[\mathrm{I} \_0\right]$} & {$\left[\mathrm{I} \_1\right]$} & {$\left[\mathrm{I} \_0\right]$} & {$\left[\mathrm{I} \_1\right]$} \\
\hline \multicolumn{2}{|c|}{$\mathbf{1 0}$} & \multicolumn{2}{|c|}{$\mathbf{2 \%}$} & \multicolumn{2}{|c|}{$\mathbf{2 . 5 \%}$} & \multicolumn{2}{c|}{$\mathbf{1 \%}$} \\
\hline Lower & Upper & Lower & Upper & Lower & Upper & Lower & Upper \\
\hline 2.17 & 3.19 & 2.72 & 3.83 & 3.22 & 4.50 & 3.88 & 5.30 \\
\hline
\end{tabular}

Table 2. Results of the Bound Test for Cointegration Source: Own calculations

Before calculating the long-term coefficients of the basic ARDL model, it is necessary to determine the optimal number of lags. For this purpose, we use the Akaike Information Criterion (AIC).

I. According to the decision based on the AIC criterion, the chosen model where the dependent variable is the monetary base is ARDL (4 4 2).

The results of the specified ARDL model, with determined optimum lag length on the determinants, and the dependent variable is the monetary base, are presented in Table 3.

\begin{tabular}{|l|c|c|c|}
\hline Dependent variable: logmonetarybase ma & ( \\
\hline Independent variables & Coefficient & t -statistics & -4.20 \\
\hline logmonetarybase ma L1. & -.0664813 & 2.23 & 0.000 \\
\hline logtotalcredits ma & .3315815 & 2.92 & 0.027 \\
\hline logtotaldeposits ma & .4315119 & 0.004 \\
\hline
\end{tabular}

Table 3. Long-run Coefficients Based on the ARDL Model Source: Own Calculations

From the obtained results it is concluded that the loans and deposits have a positive and statistically significant impact on the monetary base in long-run.

The short-run dynamics of the model along with the coefficients of adjustment are presented below.

\begin{tabular}{|l|c|c|c|}
\hline \multicolumn{2}{|l|}{ Dependent variable: D.logmonetarybase ma } & t -statistics & p - value \\
\hline Independent variables & Coefficient & 7.82 & 0.000 \\
\hline logmonetarybase maLD. & .5579357 & 2.81 & 0.005 \\
\hline logmonetarybase maL2D. & .2290205 & -0.73 & 0.467 \\
\hline logmonetarybase maL3D. & -.0538357 & 0.89 & 0.377 \\
\hline logtotalcredits ma D1. & .3533214 & 0.38 & 0.702 \\
\hline logtotalcredits ma LD. & .1919 & -0.67 & 0.506 \\
\hline logtotalcredits ma L2D. & -.3255217 & -1.20 & 0.231 \\
\hline logtotalcredits ma L3D. & -.4420204 & 2.84 & 0.005 \\
\hline logtotaldeposits ma D1. & .6917571 & -2.39 & 0.018 \\
\hline logtotaldeposits ma LD. & -.610349 & & \\
\hline
\end{tabular}

Table 4. Short-run Coefficients Based on the ARDL Model Source: Own calculations

From the obtained results of the short-run dynamics, it can be concluded that deposits have an impact on the monetary base, with 1 (one) and 2 (two) lags delay.

II. According to the decision based on the AIC criterion the selected model where the dependent variable are the total deposits, is ARDL (2 4 4).

The results of the specified ARDL model are presented in Table 5.

\begin{tabular}{|l|c|c|c|}
\hline \multicolumn{2}{|l|}{} \\
\hline Dependent variable: logtotaldeposits ma & p - value \\
\hline Independent variables & Coefficient & t -statistics & 0.126 \\
\hline logtotaldeposits ma L1. & .005936 & 1.54 & 0.229 \\
\hline logtotalcredits ma & .6580631 & 1.21 & 0.556 \\
\hline logmonetarybase ma & .4267911 & 0.59 & \\
\hline
\end{tabular}

Table 5. Long-run Coefficients Based on the ARDL Model Source: Own calculations

The results obtained in the long run are inconsistent; the zero hypothesis that there is causality in the long run between these three variables can neither be confirmed nor rejected, as it lies between the lower and upper bounds. The short-run dynamics of the model along with the coefficients of adjustment are presented below. 


\begin{tabular}{|l|c|c|c|}
\hline \multicolumn{2}{|l|}{} \\
\hline Dependent variable: D.logtotaldeposits ma & t -statistics & p - value \\
\hline Independent variables & Coefficient & 15.17 & 0.000 \\
\hline logtotaldeposits ma LD. & .7946709 & 3.21 & 0.002 \\
\hline logtotalcredits ma D1. & .3853894 & -1.59 & 0.114 \\
\hline logtotalcredits ma LD. & -.2443061 & -0.48 & 0.631 \\
\hline logtotalcredits ma L2D. & -.0725855 & -0.22 & 0.829 \\
\hline logtotalcredits ma L3D. & -.024542 & 3.26 & 0.001 \\
\hline logmonetarybase ma D1. & .0711001 & -1.11 & 0.271 \\
\hline logmonetarybase ma LD. & -.0282185 & -1.51 & 0.134 \\
\hline logmonetarybase ma L2D. & -.0384266 & 1.10 & 0.272 \\
\hline logmonetarybase ma L3D. & .0250746 & & \\
\hline
\end{tabular}

Table 6. Short-run Coefficients Based on the ARDL Model Source: Own Calculations

From the obtained results of the short-run dynamics it can be concluded that the total credits and the monetary base have a positive influence on the increase of the total deposits with 1 (one) lag period.

III. According to the decision based on the AIC criterion, the selected model where the dependent variables are the total credits, is ARDL (4 30 ).

The results of the specified ARDL model are presented in Table 7.

\begin{tabular}{|l|c|c|c|}
\hline \multicolumn{4}{|l|}{ Dependent variable: logtotalcredits_ma } \\
\hline Independent variables & Coefficient & t -statistics & p - value \\
\hline logtotalcredits_ma L1. & -.0016129 & -0.83 & 0.409 \\
\hline logtotaldeposits_ma & 1.024959 & 0.84 & 0.402 \\
\hline logmonetarybase_ma & -.1243067 & -0.08 & 0.940 \\
\hline
\end{tabular}

Table 7. Long-run Coefficients Based on the ARDL Model Source: Own Calculations

From the obtained results it is concluded that the total deposits and the monetary base have no impact on the total loans in the long-run.

The short-run dynamics of the model along with the coefficients of adjustment are presented below.

\begin{tabular}{|l|c|c|c|}
\hline \multicolumn{2}{|l|}{ Dependent variable: D.logtotalcredits_ma } \\
\hline Independent variables & Coefficient & t -statistics & p - value \\
\hline logtotalcredits_ma LD. & .7785161 & 10.90 & 0.000 \\
\hline logtotalcredits_ma L2D. & .0271216 & 0.30 & 0.762 \\
\hline logtotalcredits_ma L3D. & .0441749 & 0.66 & 0.507 \\
\hline logtotaldeposits_ma D1. & .1710992 & 3.99 & 0.000 \\
\hline logtotaldeposits_ma LD. & -.1541381 & -2.62 & 0.009 \\
\hline logtotaldeposits_ma L2D. & .1750923 & 3.90 & 0.000 \\
\hline
\end{tabular}

Table 8. Short-run Coefficients Based on the ARDL Model Source: Own Calculations

From the obtained results of the short-run dynamics it can be concluded that the total deposits have a significant impact on the total loans.

The results of the short and long run obtained by the ARDL econometric model in all three previously analyzed cases can be presented in the following table:

\begin{tabular}{|l|l|}
\hline Long-run & logtotalcredits $\mathrm{ma} \mathrm{и} \mathrm{logtotaldeposits} \mathrm{ma} \rightarrow$ logmonetarybase ma \\
\hline Short-run & logtotaldeposits $\mathrm{ma} \leftrightarrow$ logmonetarybase ma \\
\cline { 2 - 2 } & logtotalcredits $\mathrm{ma} \leftrightarrow$ logtotaldeposits ma \\
\hline
\end{tabular}

\section{Table 9. Conclusion}

The results obtained in the short-run, along with their channel of interpretation through the credit transmission mechanism, support the theory of endogenous money, as bank loans affect the level of bank deposits, which in turn affect the level of the monetary base, i.e. the money creation process in the Republic of Macedonia is mainly determined by the lending activity of commercial banks towards households and firms. The monetary base in the long-run is driven by the demand for and supply of loans.

Although we have shown that the monetary base in the short run can affect the level of bank deposits, we still saw that both bank deposits in the short run have an impact on bank loans. In other words, the exogenous increase in the monetary base may affect the demand for deposits, because it increases the amount of liquidity held by 
commercial banks. This amount of deposits (i.e. new liquidity created by the central banks) further influences the level of loans approved by commercial banks. The outcome that the causality between loans and deposits goes in the opposite direction can be explained by the fact that bank deposits are the largest percentage of the total private wealth in Macedonia, because due to weak investment opportunities and for the sake of security people save in bank, while in highly developed economies a small portion of the total wealth is in deposits.

From all of the above, it follows that the money supply in the Republic of Macedonia is endogenously determined by the credit activity of the commercial banks in the long and short run, yet the central bank has a significant influence on the money supply in the short run. Namely, if according to the theory of endogenous money, demand for credits plays an important role for entering new money in the real economy (eg. to increase the demand for loans to firms and households, instead of increasing the supply of funds by the central bank), in the Republic of Macedonia, besides the demand for loans, the exogenous setting of the money supply by the central bank is not excluded, especially during the shocks in the real economy. In other words, exogenous monetary policies based on control of the supply of money can positively affect the amount of liquidity held by commercial banks and, hence, increase the supply of loans, but the demand for loans still matters when stimulating the entrance of liquidity into the real economy.

\section{Conclusion}

Using logarithmic and deseasonalized data on the monetary base, total loans and total deposits, the ARDL econometric model was implemented to examine the hypothesis of the Post-Keynesian view of the endogeneity of the money supply in the case of the Republic of Macedonia.

In the long run, empirical findings suggest that there is causality, i.e. loans and deposits have an impact on the monetary base, which is in line with the theory of endogenous money. The monetary base in long-run is driven by the demand for and supply of loans. The money creation process in the Republic of Macedonia is mainly determined by the credit activity of the commercial banks towards households and firms.

The results obtained in the short run suggest a bidirectional causality between the total loans and the total deposits, as well as between the total deposits and the monetary base. It follows that bank loans affect the level of bank deposits, which in turn affect the level of the monetary base. However, on the other hand, the fact that the monetary base has an impact on deposits, and hence deposits on loans, is not in line with the theory of cash endowment. This means that exogenous monetary policies based on the control of money supply, can positively affect the amount of liquidity held by commercial banks and, hence, to increase the supply of loans, but the demand for loans still matters when stimulating the entrance of liquidity into the real economy. It follows that the central bank can effectively determine the money supply especially in the short run.

Considering the fact that the Republic of Macedonia has a fixed exchange rate regime, the monetary base is largely determined by the foreign exchange interventions of the NBRM, i.e. the need to defend the exchange rate, regardless of lending. For small and open economy like the Republic of Macedonia, the monetary policy control over the money supply is greater. We should also have in mind that bank deposits are the largest percentage of the total private wealth in Macedonia because, due to weak investment opportunities and for safety, people save in a bank, while in highly developed economies only a small part of the total wealth is in deposits.

The implications of this analysis suggest that the lending activity of commercial banks has a significant share in the money creation process in the Republic of Macedonia, which can facilitate the economic growth and markets development. Monetary policy can really affect the financial environment in the short and long run. Consistent monetary policies facilitate the economic activity.

\section{References}

- Ahmad, N. and Ahmet, F. (2006), "The long-run and Short-run Endogeneity of Money Supply in Pakistan: An Empirical investigation”. State Bank of Pakistan - Research Bullettin, Vol.2.

- Alexey, P. (2016), “A note on money creation in emerging market economies”, Bank of Finland, BOFIT Institute for Economies in Transition, Discussion Papers.

- Blanchard, O. (2011). Macroeconomics (5th ed.). Boston: Pearson.

- $\quad$ Enrico, S., L. and Matteo, D. (October, 2017), “The money creation process: A theoretical and empirical analysis for the US”, Roma Tre University, MPRA Paper No. 81970.

- $\quad$ Frank, R. H. \&Bernanke, B. S. (2013). Principles of economics (5th ed.). New York: McGraw-Hill/Irwin.

- Haghighat, J. (2012), “The Endogenous Money In Iran: What it is and Why it Matters", International Journal of Trade, Economics and Finance, Vol. 3, No. 2.

- James, T.(July 24, 1963), "Commercial Banks as Creators of "Money"', Cowles foundation for research in Economics, Yale University, Paper No.159.

- Jan, G. (October 2, 2014), "Introduction to money creation”, TAOLAM. 
- Mankiw, N. G. (2012). Principles of Macroeconomics (6th ed.). Mason, OH: Cengage Learning.

- Michael, M.L., Amar, R. \& Ryland, T. (2014a). "Money in the modern economy: An introduction", Bank of England. Quarterly Bulletin, Q1, 2014.

- Michael, M.L., Amar, R. \& Ryland, T. (2014b). "Money creation in the modern economy”, Bank of England. Quarterly Bulletin, Q1, 2014.

- Milena, L. (August 2014), “The Endogenous Money Hypothesis: An Empirical Study of the Euro Area (1999- 2010)", Scientific Papers, Journal of Knowledge Management, Economics and Information Technology, Vol. IV, Issue 4.

- $\quad$ Paul, M. and Joshua, W. (2013), “The Endogenous Money Hypothesis - Empirical Evidence from the United States (1959-2008)", SSRN eJournals, available at https://papers.ssrn.com/sol3/papers.cfm?abstract_id=2355178.

- Pesaran M. H., and Pesaran, B. (1997) "Working with Microfit 4.0: Interactive Econometric Analysis", Oxford University Press.

- Pesaran M. H., Shin, Y., and Smith, R. (1996) "Testing the Existence of A long-run Relationship", DAE WP 9622, Department of Applied Economics, University of Cambridge.

- Pesaran, M. H. (1997) “The Role of Economic Theory in Modelling the Long-run”, Economic Journal, vol. 107: 178-91.

- $\quad$ Pesaran, M. H. and R. P. Smith, (1998). Structural analysis of cointegrating VARs. Journal of EconomicSurveys, 12, 471-505.

- $\quad$ Pesaran, M. H. and Shin, Y. (1999). “An autoregressive distributed lag modelling approach to cointegration analysis", Chapter 11 in S. Strom (ed.), Econometrics and Economic Theory in the 20th Century: The Ragnar Frisch Centennial Symposium, Cambridge University Press, Cambridge. (Discussion Paper version).

- Pesaran, M. H., and Shin, Y. (1995) “Autoregressive Distributed Lag Modelling Approach to Cointegration Analysis”, DAE WP 9514, Department of Applied Economics, University of Cambridge.

- $\quad$ Pesaran, M. H., Shin, Y. and Smith, R. J., (2001), "Bounds testing approaches to the analysis of level relationships", Journal of Applied Econometrics, 16, 289-326.

- Rogers, J. (1929), “The Process of Inflation in France 1914-1927”, New York: Columbia University Press.

- Shanmugam, B., Nair, M. and Li, O.W. (2003), “The Endogenous Money Hypothesis: Empirical Evidence from Malaysia (1985-2000)".Journal of Post Keynesian Economics, Vol. 25, Issue 4, pp. 599-611.

- Vera, A.P. (2001), “The Endogenous money hypothesis: some evidence from Spain (1987-1998)”. Journal of Post Keynesian Economics Vol. 23, Issue 3, pp. 509-526.

- Wicksell, K. (1906), Lectures on Political Economy, Volume Two: Money, Lionel Robbins, ed., London: Routledge and Sons, Ltd.

- www.nbrm.mk 


\section{Appendix}

\section{Appendix 1: Time series in logarithmic form and eliminated seasonal influences}

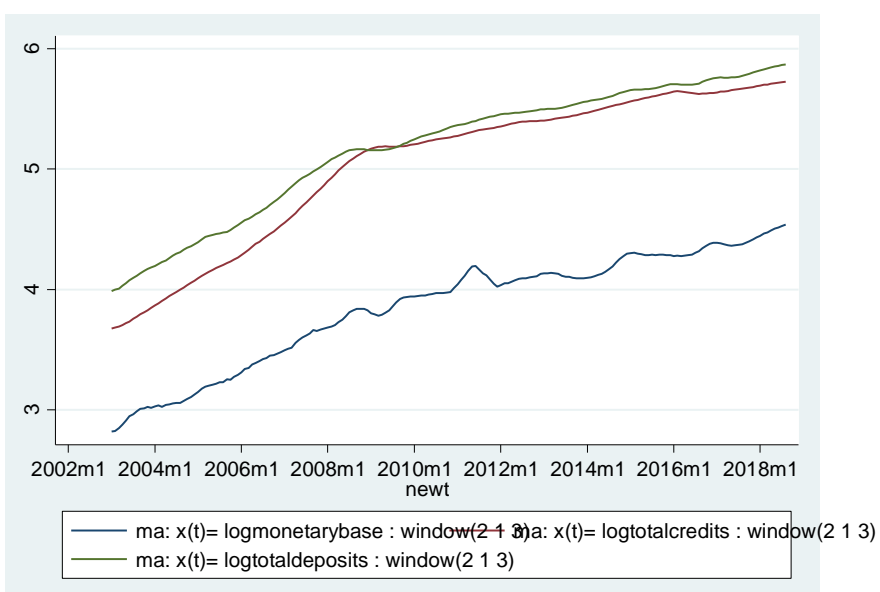

\section{Appendix 2: Unit root test}

2.a. Unit root test: Augmented Dickey-Fuller: logmonetarybase_ma, logtotalcredits_ma, logtotaldeposits_ma

$\mathrm{H}_{0}$ : Variable at level has unit root

\begin{tabular}{|l|c|c|c|c|c|}
\hline \multirow{2}{*}{ Variable } & \multicolumn{5}{|c|}{ Interpolated Dickey-Fuller } \\
\cline { 2 - 6 } & $\begin{array}{c}\text { Test } \\
\text { Statistic } \\
\mathbf{z}(\mathbf{t}) *\end{array}$ & $\begin{array}{c}\mathbf{1 \%} \\
\text { Critical } \\
\text { Value }\end{array}$ & $\begin{array}{c}\mathbf{5 \%} \text { Critical } \\
\text { Value }\end{array}$ & $\begin{array}{c}\mathbf{1 0 \%} \\
\text { Critical } \\
\text { Value }\end{array}$ & Заклучок \\
\hline logmonetarybase_ma & -1.645 & -3.482 & -2.884 & -2.574 & $\mathrm{I}(1)$ \\
\hline logtotalcredits_ma & -3.421 & -3.482 & -2.884 & -2.574 & $\mathrm{I}(0)$ \\
\hline logtotaldeposits_ma & -3.522 & -3.482 & -2.884 & -2.574 & $\mathrm{I}(0)$ \\
\hline
\end{tabular}

Note: Because the Augmented Dickey-Fuller test has autocorrelation problems, it is necessary to determine the lag length before it is applied. This is done in the statistical software STATA for each time series and are determined 2 lags for the monetary base, 2 lags for loans and 2 lags for deposits.

* $z(t)$ is a statistical test that applies for series with over 30 observations and standard normal distribution

Source: Own calculations

2.b. Unit root test: Phillips-Perron:Iogmonetarybase_ma,logtotalcredits_ma, logtotaldeposits_ma $\mathrm{H}_{0}$ : Variable at level has unit root

\begin{tabular}{|l|c|c|c|c|c|}
\hline \multirow{2}{*}{ Variable } & \multicolumn{5}{|c|}{ Interpolated Dickey-Fuller } \\
\cline { 2 - 6 } & $\begin{array}{c}\text { Test } \\
\text { Statistic } \\
\mathbf{z}(\mathbf{t}) *\end{array}$ & $\begin{array}{c}\mathbf{1 \%} \\
\text { Critical } \\
\text { Value }\end{array}$ & $\begin{array}{c}\mathbf{5 \%} \text { Critical } \\
\text { Value }\end{array}$ & $\begin{array}{c}\mathbf{1 0 \%} \\
\text { Critical } \\
\text { Value }\end{array}$ & Заклучок \\
\hline logmonetarybase_ma & -2.354 & -3.481 & -2.884 & -2.574 & $\mathrm{I}(0)$ \\
\hline logtotalcredits_ma & -5.927 & -3.481 & -2.884 & -2.574 & $\mathrm{I}(1)$ \\
\hline logtotaldeposits_ma & -6.201 & -3.481 & -2.884 & -2.574 & $\mathrm{I}(1)$ \\
\hline
\end{tabular}

Source: Own calculations 


\section{Appendix 3:_Bound test for cointegration}

\subsection{Dependent variable: monetary base}

Pesaran/Shin/Smith (2001) ARDL Bounds Test

HO: no levels relationship $\quad F=6.345$

$t=-4.196$

Critical Values (0.1-0.01), F-statistic, Case 1

\begin{tabular}{r|ccccccccr}
$\mid$ & {$\left[I_{-} 0\right]$} & {$\left[I_{-} 1\right]$} & {$\left[I_{-} 0\right]$} & {$\left[I_{-} 1\right]$} & {$\left[I_{-} 0\right]$} & {$\left[I_{-} 1\right]$} & {$\left[I_{-} 0\right]$} & {$\left[I_{-} 1\right]$} \\
$\mid$ & $L_{-} 1$ & $L_{-} 1$ & $L_{-} 05$ & $L_{-} 05 \mid$ & $L_{-} 025$ & $L_{-} 025$ & $L_{-} 01$ & $L_{-} 01$ \\
-1 & 2.17 & 3.19 & 2.72 & 3.83 & 3.22 & 4.50 & 3.88 & 5.30
\end{tabular}

accept if $F<$ critical value for $I(0)$ regressors

reject if $F>$ critical value for I(1) regressors

Critical Values (0.1-0.01), t-statistic, Case 1

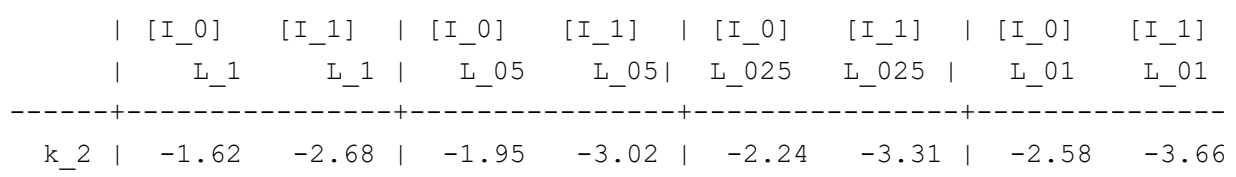

accept if $t>$ critical value for $I(0)$ regressors

reject if $t<$ critical value for $I(1)$ regressors

$\mathrm{k}$ : \# of non-deterministic regressors in long-run relationship

Critical values from Pesaran/Shin/Smith (2001)

\subsection{Dependent variable: Total deposits}

Pesaran/Shin/Smith (2001) ARDL Bounds Test

HO: no levels relationship $\quad F=2.176$

$$
\mathrm{t}=1.538
$$

Critical Values (0.1-0.01), F-statistic, Case 1

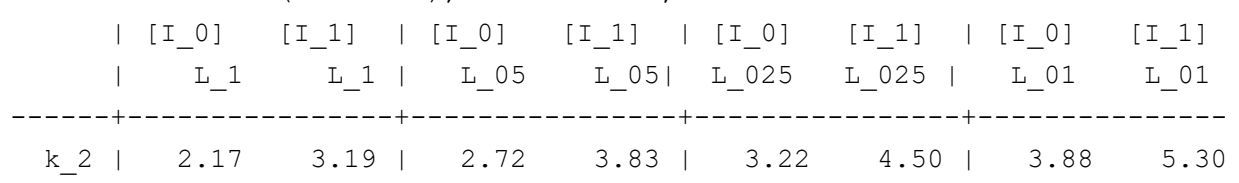

accept if $F<$ critical value for $I(0)$ regressors

reject if $F>$ critical value for $I(1)$ regressors

Critical Values (0.1-0.01), t-statistic, Case 1

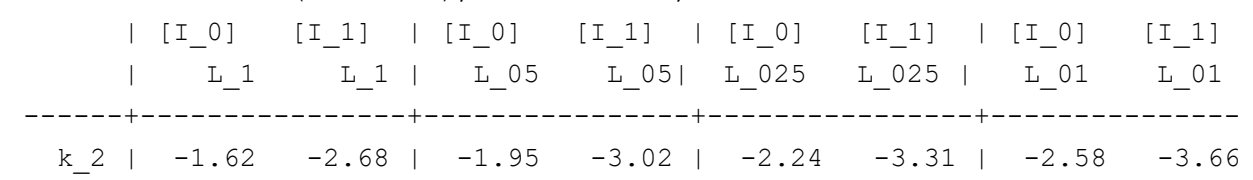

accept if $t>$ critical value for $I(0)$ regressors

reject if $t<$ critical value for $I(1)$ regressors

$\mathrm{k}$ : \# of non-deterministic regressors in long-run relationship

Critical values from Pesaran/Shin/Smith (2001) 


\subsection{Dependent variable: total loans}

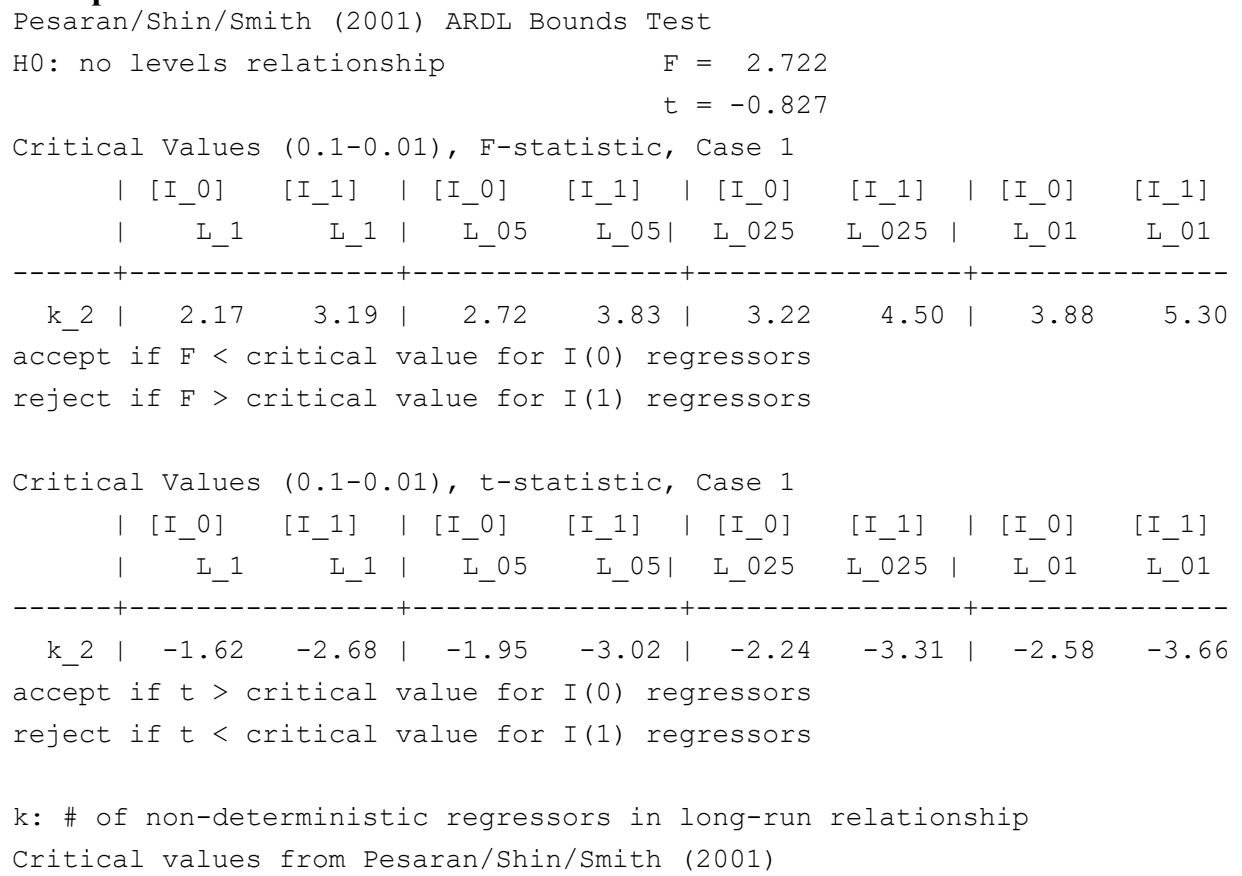

\section{Appendix 4: Estimating the long-run causality and short-run dynamics of the ARDL model - dependent variable: monetary base}

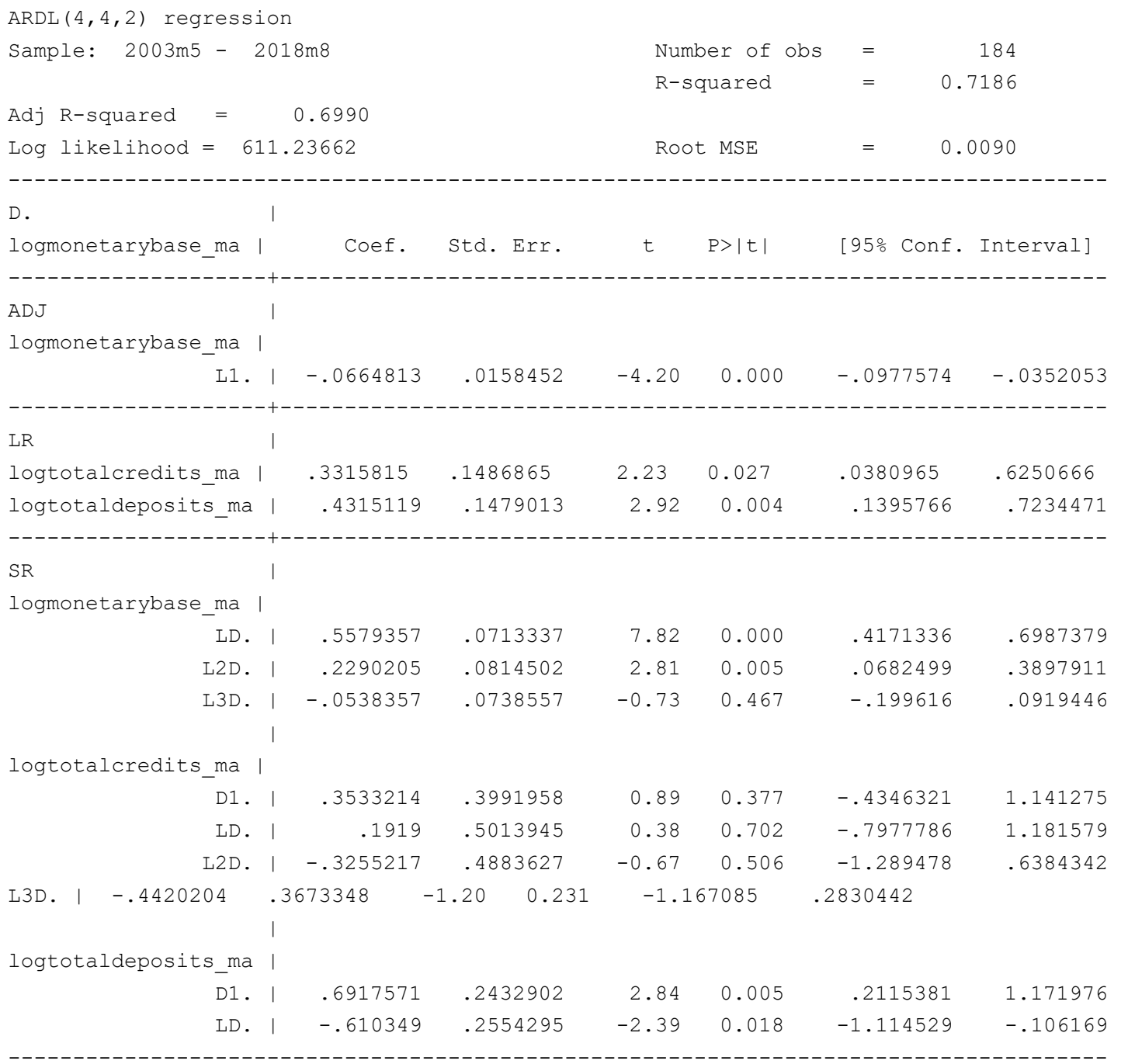


Appendix 5: Estimating the long-run causality and short-run dynamics of the ARDL model - dependent variable: total deposits

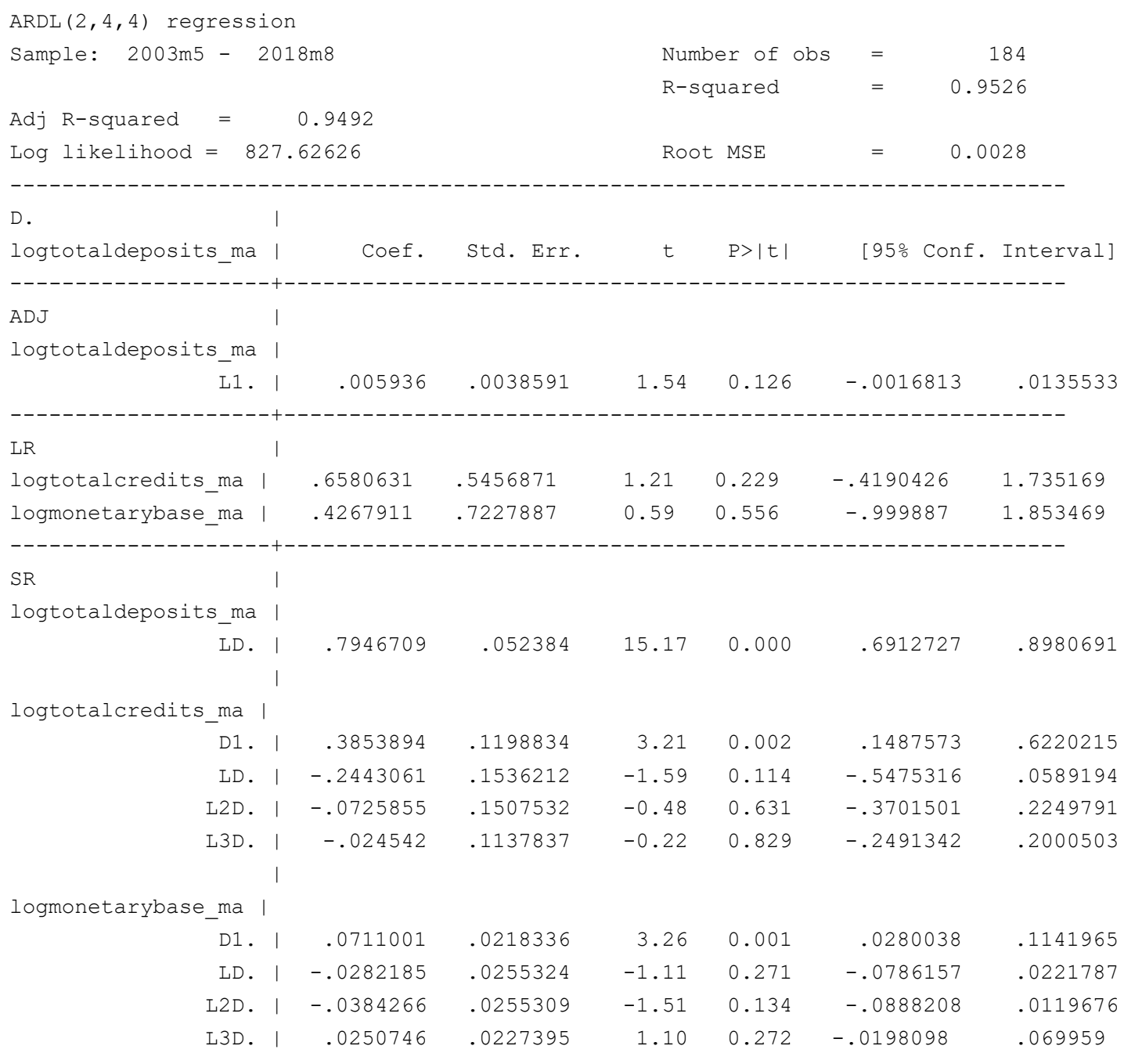


Appendix 6: Estimating the long-run causality and short-run dynamics of the ARDL model - dependent variable: total loans

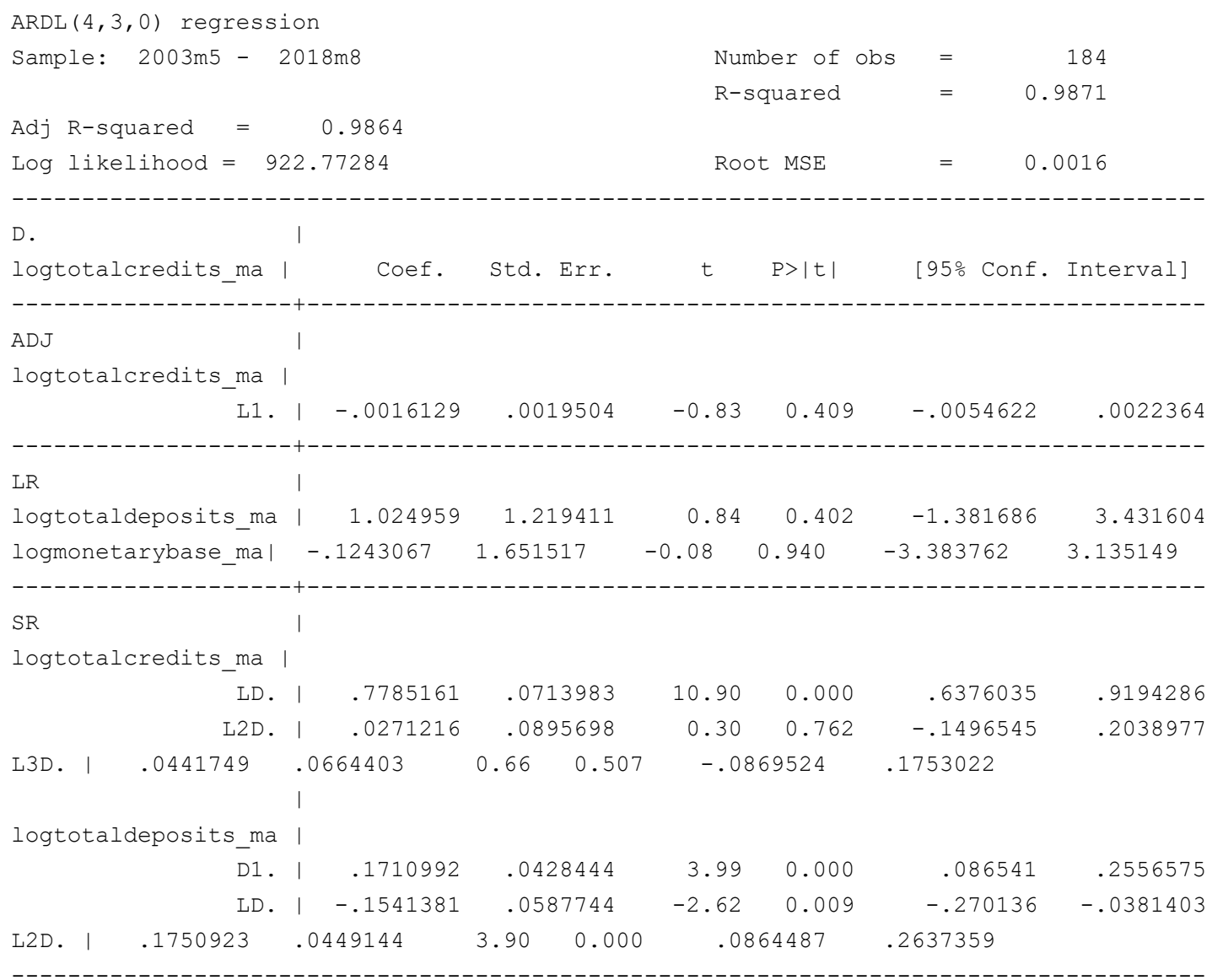

